\title{
Analisis Pengaruh Pembiayaan Syariah dan Variabel Makro Ekonomi Terhadap Ekspor Indonesia (Studi Pada BUS Devisa dan LPEI)
}

Analysis of the effect of sharia financing and macroeconomic variables on Indonesian export (Study of foreign exchange Islamic bank and LPEI)

\section{Rizky Rahmawati}

Program Studi D4 Keuangan Syariah, Politeknik Negeri Bandung

E-mail: rizky.rahmawati.ksy16@polban.ac.id

\section{Djoni Djatnika}

Jurusan Akuntansi, Politeknik Negeri Bandung

E-mail: djoni.djatnika@gmail.com

\begin{abstract}
This research aims to determine the effect of financing channeled by Foreign Exchange Islamic Bank, LPEI sharia financing, inflation and exchange rates simultaneously and partially on Indonesian exports in 2015 - 2019. The sampling technique in this research is purposive sampling method and used secondary data from Bank Indonesia, BPS, OJK and the financial statements of each bank. The research used quantitative method. Data analysis techniques used is multiple linear regression ordinary least Square (OLS) using software Eviews 9. The results of this research indicate that simultaneously the financing channeled by Foreign Exchange Islamic Bank, LPEI sharia financing, inflation and exchange rates have a significant effect on Indonesian exports. Partially the financing channeled by foreign exchange Islamic Bank and inflation does not affect on Indonesian exports. LPEI sharia financing and exchange rates has a significant positive effect on Indonesian exports.
\end{abstract}

Keywords: Sharia Financing, Inflation, Exchange Rates, Indonesian Export

\section{Pendahuluan}

Kegiatan ekspor diandalkan oleh beberapa negara di dunia sebagai penyumbang pendapatan terbesar bagi perekonomian negaranya. Indonesia, Malaysia dan Brunei Darussalam sebagai negara muslim terbesar di ASEAN pun tak lepas dari kegiatan ekspor.

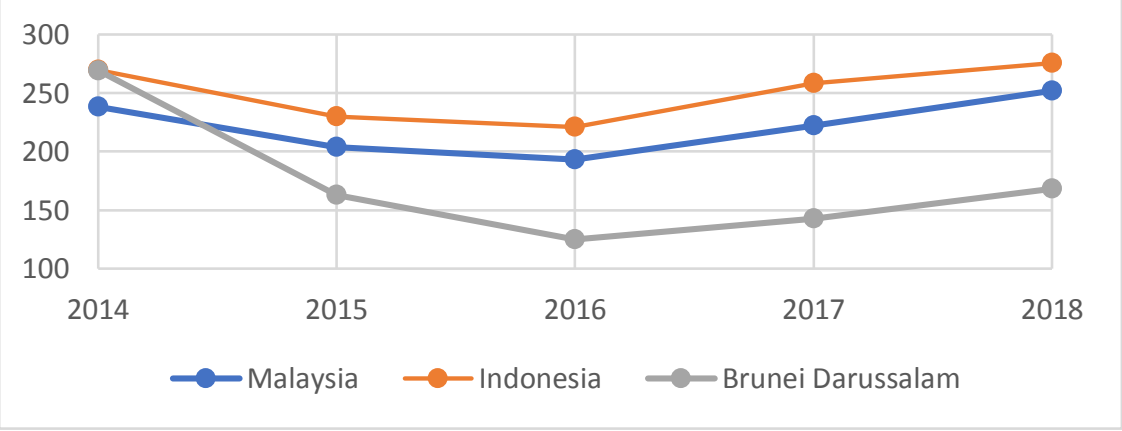

Gambar 1. Nilai Ekspor 3 Negara Muslim Terbesar di ASEAN

Sumber: Worldbank, data diolah 
Berdasarkan grafik 1, Indonesia memiliki nilai ekspor yang lebih tinggi dibandingkan Malaysia dan Brunei Darussalam pada tahun 2014-2018. Hal tersebut menandakan bahwa Indonesia mempunyai potensi yang besar terhadap ekspor.

Sementara itu, awal tahun 2018 Amerika Serikat dan China memulai perang dagang hingga saat ini. Berita yang dimuat idntimes.com atas hasil wawancaranya dengan Imam Pambagyo selaku Direktur Jenderal Perundingan Perdagangan Internasional, dikatakan ada 3 efek perang dagang tersebut kepada Indonesia, yaitu peluang ekspor untuk Indonesia, penurunan ekspor untuk bahan mentah Indonesia ke China dan AS, dan memaksimalkan trade diversion yang mungkin terjadi (Shemi, 2019). Berdasarkan potensi ekspor yang dimiliki, Indonesia dapat mengambil kesempatan peluang ekspor dari dampak perang dagang tersebut.

Industri keuangan syariah yang berwujud bank maupun non bank dapat berperan dalam pengambilan kesempatan peluang ekspor tersebut dengan menyalurkan pembiayaan syariah kepada eksportir serta UMKM beriorientasi ekspor. Dimana, berdasarkan tabel 1, masih ada beberapa UMKM berorientasi ekspor yang belum tersentuh pembiayaan dari bank maupun lembaga keuangan lain.

Tabel 1. Database UMKM Produk Ekspor

Provinsi DKI Jakarta dan Jawa Barat per Agustus 2019

Sektor: Industri Pengolahan

\begin{tabular}{|c|l|c|c|}
\hline No & \multicolumn{1}{|c|}{ Sub Sektor } & $\begin{array}{c}\text { Jumlah } \\
\text { UMKM }\end{array}$ & $\begin{array}{c}\text { Belum Mendapat Pembiayaan } \\
\text { Bank/Lembaga Keuangan lainnya }\end{array}$ \\
\hline 1 & Makanan, minuman \& tembakau & 16 & 14 \\
\hline 2 & Tekstil, barang kulit \& alas kaki & 32 & 18 \\
\hline 3 & Barang kayu \& hasil hutan lainnya & 20 & 5 \\
\hline 4 & Pupuk, kimia \& barang dari karet & 1 & 1 \\
\hline 5 & Semen \& barang galian bukan logam & 14 & 4 \\
\hline 6 & Logam dasar besi \& baja & 2 & 2 \\
\hline 7 & Alat angkutan, mesin \& peralatannya & 2 & 1 \\
\hline 8 & Barang lainnya & 16 & 8 \\
\hline
\end{tabular}

Sumber: Bank Indonesia, data diolah

Bank umum syariah berbentuk bank devisa merupakan satu dari beberapa lembaga keuangan syariah yang dapat menjadi pilihan untuk melakukan kegiatan transaksi ekspor yang berhubungan dengan transaksi valuta asing. Bank devisa ialah bank yang diperbolehkan behubungan dengan mata uang asing secara utuh dan mengadakan transaksi ke luar negeri (Kasmir, 2002).

Lembaga keuangan syariah non bank yang dapat menjadi pilihan lain yaitu Lembaga Pembiayaan Ekspor Nasional (LPEI) yang merupakan salah satu IKNB syariah sekaligus Lembaga Keuangan Khusus yang diberdirikan pemerintah selaras dengan Undang-Undang RI No.2 Tahun 2009 perihal LPEI (Pemerintah Indonesia, 2009). Tujuan didirikannya LPEI yaitu untuk mendorong program ekspor nasional. LPEI dikategorikan sebagai unit usaha syariah karena menjalankan dua prinsip dalam kegiatannya, yaitu konvensional dan syariah.

BUS devisa maupun LPEI telah menyediakan fasilitas pembiayaan yang sesuai dengan prinsip syariah. Fasilitas tersebut dilaksanakan dengan akad penyaluran dana yang berdasarkan skema bagi hasil yaitu Mudharabah dengan Musyarakah, yang menggunakan prinsip jual-beli atas skema margin yaitu Murabahah, Salam dan Istishna', yang berdasarkan skema fee atau ujroh yaitu Ijarah (prinsip sewa) dan wadi'ah, serta akad Qardh yang merupakan akad pinjaman murni. Pilihan akad lainnya yaitu ijarah muntahiyah bit tamlik, hawalah, wakalah, dan kafalah. Dengan adanya berbagai pilihan akad tersebut nasabah memiliki banyak pilihan sesuai dengan kebutuhan pembiayaan yang 
tidak memberatkan atau merugikan nasabah dan tentunya menghindari praktik yang dilarang syariat Islam.

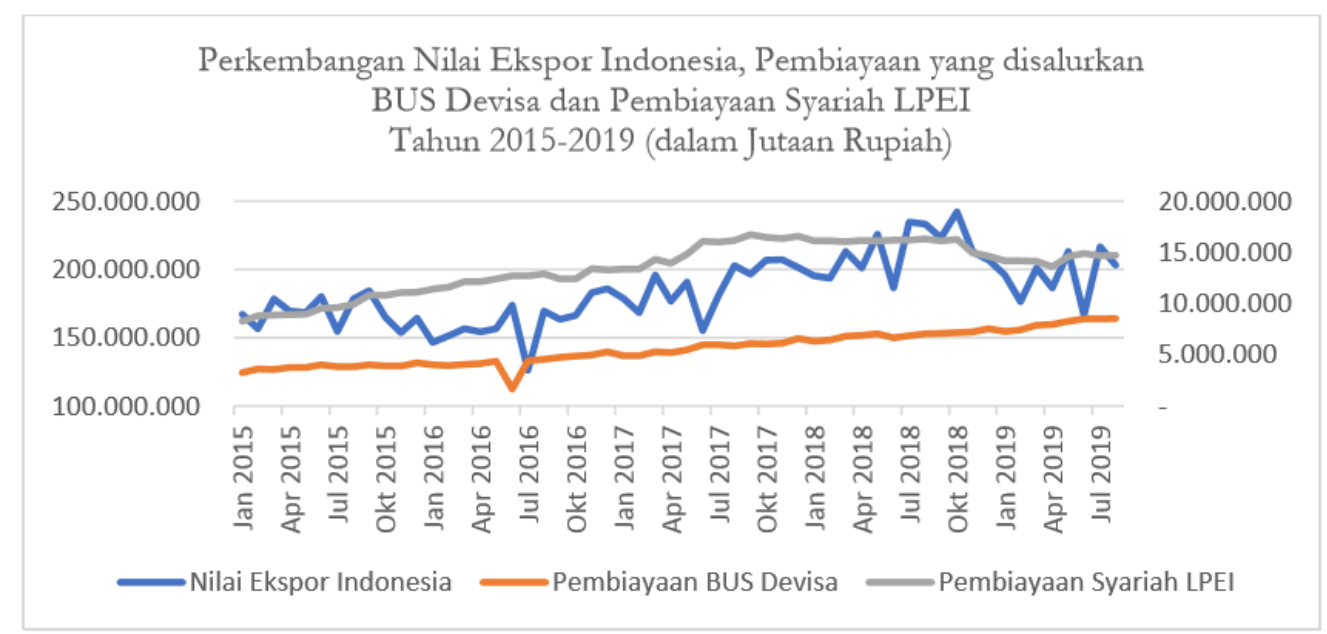

Gambar 2. Perkembangan Nilai Ekspor Indonesia, Pembiayaan yang disalurkan BUS Devisa dan Pembiayaan Syariah LPEI

Sumber: BPS, Website Resmi masing-masing BUS Devisa dan OJK, data diolah

Berdasarkan grafik pada gambar 2, perkembangan pembiayaan syariah BUS devisa dan LPEI sejalan dengan fluktuasi perkembangan ekspor Indonesia. Sehingga, diharapkan semakin banyak pembiayaan syariah yang disalurkan akan semakin meningkatkan ekspor Indonesia.

Penelitian terdahulu menuturkan bahwa pembiayaan BUS dan IKNB syariah berdampak negatif terhadap ekspor di Indonesia (Rusmita \& Cahyono, 2016). Peneliti menyimpulkan penyebab pembiayaan BUS dan IKNB Syariah berpengaruh negatif karena BUS lebih banyak melakukan pembiayaan yang bersifat konsumtif. Peneliti lain menyatakan bahwa selama ini pembiayaan ekspor syariah yang dilakukan oleh LPEI belum optimal dan masih bersifat terbatas, ditinjau dari model layanan pembiayaan syariah, struktur maupun dari produk yang ditawarkan (Mahrus \& Yulianto, 2017).

\section{Perkembangan Inflasi dan Nilai Ekspor Indonesia Tahun 2015 - 2019}

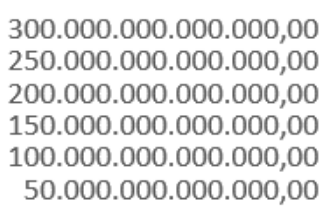

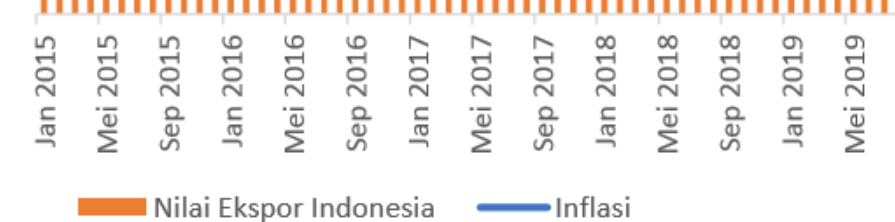

$8,00 \%$ $6,00 \%$ $4,00 \%$ $2,00 \%$ $0,00 \%$

Gambar 3. Perkembangan Inflasi dan Nilai Ekspor Indonesia Sumber: BPS dan Bank Indonesia, data diolah

Inflasi dan kurs merupakan aspek makro yang secara teori mempunyai hubungan negatif terhadap ekspor. Hubungan negatif inflasi terhadap ekspor terlihat pada grafik pada gambar 3, tahun 2015 ekspor Indonesia cenderung turun saat inflasi meningkat. Sebaliknya, ekspor cenderung 
meningkat ketika inflasi menurun pada Mei 2017 sampai September 2018.

Hubungan negatif antara inflasi dan ekspor diungkapkan dalam penelitian terdahulu yang mengungkapkan bahwa inflasi mempunyai hubungan negatif dengan ekspor Malaysia (Yee \& dkk, 2016). Di India, diungkap bahwa inflasi berpengaruh negatif terhadap ekspor India (Gururaj, Satishkumar, \& Kumar, 2016). Begitupun penelitian yang dilaksanakan oleh Rusmita dan Cahyono (2016), Yanti dan Sudirman (2017) dan Wardhana (2011) mengungkapkan bahwa inflasi secara parsial berdampak negatif signifikan pada ekspor Indonesia. Sedangkan, penelitian lain mengungkapkan perbedaan hasil penelitian yang menyatakan bahwa inflasi dan ekspor memiliki hubungan positif. Diungkapkan bahwa inflasi mempunyai hubungan positif dengan ekspor nonoil di Iran (Farhadi, Ghaffari, \& Taghavi, 2010). Inflasi secara parsial berdampak positif signifikan pada ekspor Indonesia (Anshari, Khilla, \& Permata, 2017).

Adapun hubungan antara kurs dan ekspor dilihat ketika kurs mata uang rupiah terdepresiasi kepada mata uang luar negeri, kemudian berakibat pada peningkatan ekspor, begitupun sebaliknya. Saat nilai mata uang dalam negeri menguat maka akan menurunkan ekspor.

Hasil penelitian yang mengungkapkan hubungan negatif antara kurs dengan ekspor dilakukan oleh Gururaj, Satishkumar dan Kumar (2016) yang mengungkapkan bahwa kurs berpengaruh negatif terhadap ekspor di India. Begitupun penelitian yang dilaksanakan Ginting (2013) dan Setianto (2014) yang mengungkapkan bahwa kurs secara parsial berdampak negatif signifikan kepada ekspor Indonesia. Sedangkan, peneliti lain mengungkapkan adanya hubungan positif antara kurs dengan ekspor. Dikatakan bahwa kurs mempunyai hubungan positif dengan ekspor di Malaysia (Yee \& dkk, 2016). Kurs berdampak positif signifikan kepada ekspor Bangladesh (Rahman, 2010). Rusmita dan Cahyono (2016) dan Marbun (2017) mengungkapkan bahwa kurs berdampak positif pada ekspor Indonesia.

Penelitian yang telah disebutkan sebelumnya berbeda dengan penelitian yang mengatakan bahwa inflasi serta kurs rupiah tak mempengaruhi volume ekspor (Azaria \& Irawan, 2019). Penelitian sebelumnya belum banyak yang menganalisis tentang ekspor yang dikaitkan dengan pembiayaan syariah dan terdapat perbedaan hasil penelitian dari pengaruh inflasi dan kurs terhadap ekspor. Berdasarkan hal tersebut, melihat besarnya potensi ekspor Indonesia serta adanya peluang ekspor dari dampak perang dagang, maka penelitian ini berfokus untuk mengetahui pengaruh pembiayaan syariah dari lembaga keuangan syariah serta inflasi dan kurs terhadap ekspor Indonesia.

\section{Kajian Pustaka}

\subsection{Pembiayaan Syariah BUS Devisa dan LPEI}

Bank umum syariah berstatus devisa yakni BUS yang ditunjuk oleh Bank Indonesia agar dapat menyimpan dan memperjualbelikan devisa serta mengadakan lalu lintas pembayaran luar negeri. Pembiayaan adalah kegiatan utama bank dalam menyalurkan dana supaya menghasilkan keuntungan untuk bank (Apriyanthi, Purbayati, \& Setiawan, 2020). Dituturkan bahwa pembiayaan merupakan fasilitas pengadaan uang ataupun tagihan yang disetarakan dengan uang, dimana setelah jangka waktu tertentu pihak yang menerima pembiayaan wajib mengembalikan fasilitas tersebut dengan imbalan atau bagi hasil berdasar dari kesepakatan antar pihak terkait (Kasmir, 2002).

Menurut UU Nomor 2 Tahun 2009 tentang LPEI, yang dimaksud dengan pembiayaan syariah yaitu fasilitas pembiayaan tunai serta non-tunai, yang mewajibkan pihak yang menerima pembiayaan agar melakukan pengembalian fasilitas seusai batas waktu terbatas beserta imbalan atau bagi hasil.

\subsection{Inflasi}

Inflasi dapat diterjemahkan sebagai kenaikan rata-rata tingkat harga secara terus menerus 
(McEarhern \& Wiliam, 2000). Hubungan inflasi dengan ekspor yaitu negatif. Apabila inflasi meningkat maka ekspor akan cenderung berkurang dikarenakan peningkatan harga barang secara umum dapat mempengaruhi mahalnya biaya produksi barang ekspor. Teori lain mengatakan bahwa inflasi yang tinggi akan berpengaruh dalam penurunan ekspor karena barang dan jasa pada saat itu kurang kompetitif akibat dari peningkatan harga barang dan jasa yang dihasilkan maupun yang ditawarkan (Ball, 2005).

\subsection{Kurs}

Kurs diartikan sebagai tarif satu satuan mata uang untuk satuan mata uang lain (Samuelson \& Nordhaus, 1994; Tripuspitorini \& Setiawan, 2020). Hubungan negatif kurs dengan ekspor dapat dijelaskan oleh model Mundell Fleming. Model tersebut menunjukkan bahwa perubahan ekspor dapat diakibatkan oleh depresiasi atau apresiasi kurs. Apabila kurs terdepresiasi, dimana secara relatif mata uang rupiah melemah terhadap mata uang luar negeri, kemudian ekspor cenderung meninggi.

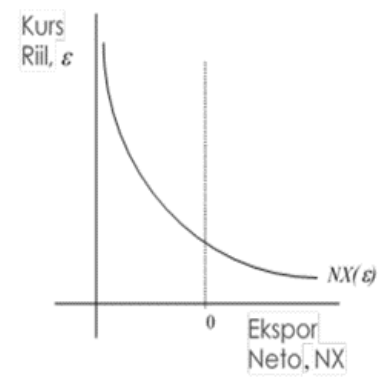

Gambar 4. Model Mundell Fleming

Sumber: Mankiw N. G., 2003 Macroeconomic5th

\subsection{Ekspor}

Berdasarkan UU No. 2 Tahun 2009 mengenai LPEI, ekspor merupakan aktivitas mengirim barang dan/atau jasa dari wilayah pabean Indonesia. Berikut merupakan beberapa faktor yang dapat mempengaruhi ekspor (Mankiw N. G., 2006):

1. Selera konsumen dalam maupun luar negeri.

2. Tarif produk domestik dan mancanegara.

3. Kurs untuk menetapkan jumlah mata uang saat ditukarkan dengan mata uang negara lain.

4. Penghasilan konsumen antarbangsa.

5. Biaya pemindahan produk antarnegara.

6. Garis haluan pemerintah atas perniagaan internasional di negaranya.

\subsection{Hipotesis}

Berikut merupakan rumusan hipotesis dalam penelitian ini:

H1: Diduga Pembiayaan BUS devisa secara parsial berpengaruh positif signifikan terhadap Ekspor Indonesia

H2: Diduga Pembiayaan Syariah LPEI secara parsial berpengaruh positif signifikan terhadap Ekspor Indonesia

H3: Diduga Inflasi secara parsial berpengaruh negatif signifikan terhadap Ekspor Indonesia

H4: Diduga Kurs secara parsial berpengaruh negatif signifikan terhadap Ekspor Indonesia

H5: Diduga Pembiayaan BUS Devisa, pembiayaan syariah LPEI, Inflasi dan Kurs secara simultan berpengaruh signifikan terhadap Ekspor Indonesia 


\subsection{Kerangka Pemikiran}

Penelitian ini dilandaskan pada sebuah kerangka pemikiran, yaitu:

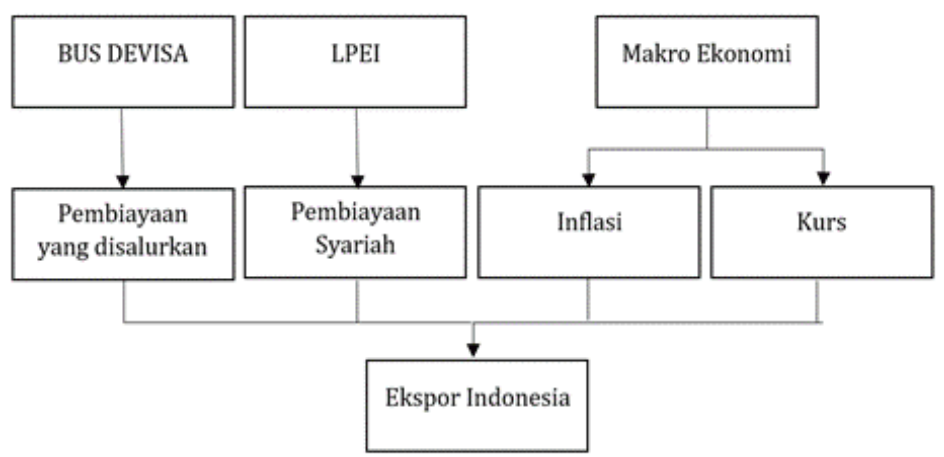

Gambar 5. Kerangka Pemikiran

Sumber: Diolah penulis

\section{Metode Penelitian}

\subsection{Metode Penelitian}

Penelitian ini memakai metode kuantitatif yang dimaknai sebagai teknik penelitian untuk meneliti populasi ataupun sampel terbatas yang mengacu pada filsafat positivisme (Sugiyono, 2011).

\subsection{Populasi dan Sampel Penelitian}

Penelitian ini mempunyai tujuh populasi BUS devisa serta satu populasi lembaga keuangan non bank syariah di Indonesia. Kemudian, teknik pengambilan sampel yang dipakai yakni purposive sampling yang menarik sampel berdasar kriteria khusus. Berikut ini kriteria yang dipakai:

1. BUS devisa yang terdaftar pada Bank Indonesia dan OJK serta mempublikasikan laporan keuangan bulanan melalui website masing-masing bank serta website OJK.

2. BUS devisa yang terdaftar sebagai bank devisa pada Januari 2015 - Desember 2019.

Berdasarkan kriteria tersebut, 6 dari 7 BUS devisa di Indonesia yang masuk dalam kriteria pemilihan sampel, yaitu:

Tabel 2. Sampel BUS Devisa

\begin{tabular}{|c|l|}
\hline No. & \multicolumn{1}{|c|}{ Nama Bank Umum Syariah } \\
\hline 1 & Bank BNI Syariah \\
\hline 2 & Bank BRISYARIAH \\
\hline 3 & Bank Maybank Syariah Indonesia \\
\hline 4 & Bank Mega Syariah \\
\hline 5 & Bank Muamalat Indonesia \\
\hline 6 & Bank Syariah Mandiri \\
\hline
\end{tabular}

Sumber: (OJK, 2018) data diolah

Kemudian, untuk populasi lembaga keuangan non bank syariah, kriteria sampel yang dipakai yakni lembaga keuangan non bank syariah khusus melayani aktivitas ekspor. Berdasarkan kriteria tersebut, sampel yang digunakan yaitu LPEI.

\subsection{Jenis Data dan Sumber Data}

Penelitian ini mempergunakan data sekunder berupa data runtun waktu bulanan. Data 
sekunder tersebut berupa laporan keuangan BUS devisa, data laporan keuangan LPEI, data inflasi dan data kurs dari tahun 2015 sampai 2019. Data tersebut bersumber dari website resmi masingmasing BUS devisa, website resmi BI OJK dan BPS. Teknik pengumpulan data yang dipakai yakni teknik dokumentasi terhadap data sekunder serta menggunakan metode kepustakaan untuk mengumpulkan literatur-literatur yang terkait dengan objek penelitian.

\subsection{Alat dan Metode Analisis Data}

Alat analisis data yang dipakai yaitu software Eviews 9. Pengukuran dilakukan dengan menganalisis data yang sudah dikumpulkan dengan menggunakan teknik analisis regresi linear berganda (multiple linear regression ordinary least Square/OLS).

Pengujian asumsi klasik dilaksanakan sebelum melakukan uji regresi untuk memastikan bahwa model regresi yang digunakan terhindar dari penyimpangan. Pengujian asumsi yang dilaksanakan ada empat, yaitu uji normalitas, multikolinearitas, heteroskedastisitas serta autokorelasi.

Uji normalitas ditujukan menguji kenormalan pada distribusi data. Memakai uji Jarque - Bera (JB) dengan nilai probabilitas $>0,05$ supaya lolos uji normalitas.

Uji multikolinearitas bermaksud untuk melihat keberadaan korelasi pada model regresi. Dilaksanakan dengan mengamati nilai variance inflation factor yang harus menunjukkan nilai VIF < 10 supaya terhindar dalam masalah multikolinearitas.

Harapan dari uji heteroskedastisitas ialah varian yang sama (homoskedastisitas) pada nilai residual atau error ( $\mu$ i) dalam model regresi. Menggunakan uji Glejser dengan nilai probabilitas $>0,05$ supaya terhindar dalam masalah heteroskedastisitas.

Uji autokorelasi bermaksud melihat apakah ada korelasi dalam model regresi linear. Memakai Durbin - Watson (DW Test) dengan pengambilan ketetapan $\mathrm{du}<\mathrm{d}<4-\mathrm{dL}$ supaya terhindar dari masalah autokorelasi.

\subsection{Model Penelitian}

Model penelitian yang dipakai, yaitu:

$$
\mathrm{Y}=\alpha+\beta 1 \mathrm{X} 1+\beta 2 \mathrm{X} 2+\beta 3 \mathrm{X} 3+\beta 4 \mathrm{X} 4+\mu
$$

Keterangan:

$$
\begin{array}{ll}
\mathrm{Y} & =\text { Nilai Ekspor Indonesia } \\
\alpha & =\text { Konstanta } \\
\beta 1 & =\text { Koefisien regresi Pembiayaan yang disalurkan BUS devisa } \\
\mathrm{X} 1 & =\text { Pembiayaan yang disalurkan BUS devisa } \\
\beta 2 & =\text { Koefisien regresi Pembiayaan Syariah LPEI } \\
\mathrm{X} 2 & =\text { Pembiayaan syariah LPEI } \\
\beta 3 & =\text { Koefisien regresi Inflasi } \\
\mathrm{X} 3 & =\text { Inflasi } \\
\beta 4 & =\text { Koefisien regresi Kurs } \\
\mathrm{X} 4 & =\text { Kurs } \\
\mu & =\text { Residual error }
\end{array}
$$




\section{Hasil dan Pembahasan}

\subsection{Hasil Analisis Data}

Berlandaskan pengolahan data yang telah dilaksanakan, berikut ini merupakan persamaan model regresi yang diperoleh:

$Y=-133.814 .756,7+0,382 X 1+3,741 X 2-9.522 .245,808 X 3+16.353,988 X 4+\mu$

Keterangan:

$\mathrm{Y} \quad=$ Nilai Ekspor Indonesia

$\mathrm{X} 1=$ Pembiayaan disalurkan BUS devisa

$\mathrm{X} 2=$ Pembiayaan syariah LPEI

$\mathrm{X} 3=$ Inflasi

$\mathrm{X} 4=$ Kurs

$\mu \quad=$ Nilai kesalahan atau residual error

\subsubsection{Uji Asumsi Klasik}

1. Uji Normalitas

Berikut merupakan hasil pemeriksaan normalitas dalam model:

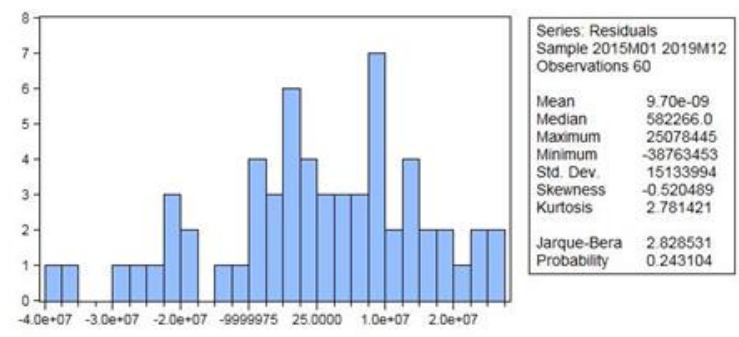

Gambar 6. Grafik Hasil Uji Jaque-Bera (JB)

Sumber: Hasil olah data Eviews 9

Bersumber pada grafik di atas dengan uji Jaque - Bera (JB), terlihat bahwa nilai probabilitas JB sebesar 0,243104 >0,05 menunjukan data terdistribusi normal.

2. Uji Multikolinearitas

Berikut merupakan hasil pengujian multikolinearitas:

Variance Inflation Factors

Date: 06/18/20 Time: 09:10

Sample: 2015M01 2019M12

Included observations: 60

\begin{tabular}{cccc}
\hline \hline Variable & $\begin{array}{c}\text { Coefficient } \\
\text { Variance }\end{array}$ & $\begin{array}{c}\text { Uncentered } \\
\text { VIF }\end{array}$ & $\begin{array}{c}\text { Centered } \\
\text { VIF }\end{array}$ \\
\hline \hline C & $2.94 \mathrm{E}+15$ & 717.5961 & NA \\
X1 & 0.056070 & 285.3251 & 2.469160 \\
X2 & 1.325309 & 61.30391 & 1.841437 \\
X3 & $4.21 \mathrm{E}+13$ & 1.709227 & 1.009309 \\
X4 & 24099799 & 1109.003 & 1.697713 \\
\hline \hline
\end{tabular}

Gambar 7. Hasil Pengujian Multikolinearitas

Sumber: Hasil olah data Eviews 9

Berlandaskan pada hasil uji di atas, seluruh variabel penelitian terbebas dari masalah multikolinearitas dengan nilai VIF pada masing-masingvvariabel, yaitu:

- Nilai VIF variabel X1 (Pembiayaan BUS devisa) adalah 2,469160<10.

- Nilai VIF variabel X2 (Pembiayaan Syariah LPEI) adalah 1,841437 < 10 .

- Nilai VIF variabel X3 (Inflasi) adalah 1,009309< 10 .

- Nilai VIF variabel X4 (Kurs) adalah 1,697713 < dari 10. 


\section{Rizky Rahmawati, Djoni Djatnika}

3. Uji Heteroskedastisitas

Berikut merupakan hasil dari uji Glejser untuk pengujian heteroskedastisitas:

\begin{tabular}{|c|c|c|c|c|}
\hline $\begin{array}{l}\text { F-statistic } \\
\text { Obs*R-squared } \\
\text { Scaled explained SS }\end{array}$ & $\begin{array}{l}0.506706 \\
2.132494 \\
1.894277\end{array}$ & \multicolumn{2}{|c|}{$\begin{array}{l}\text { Prob. F( } 4,55) \\
\text { Prob. Chi-Square }(4) \\
\text { Prob. Chi-Square }(4)\end{array}$} & $\begin{array}{l}0.7310 \\
0.7114 \\
0.7552\end{array}$ \\
\hline \multicolumn{5}{|c|}{$\begin{array}{l}\text { Test Equation: } \\
\text { Dependent Variable: ARESID } \\
\text { Method: Least Squares } \\
\text { Date: 06/18/20 Time: } 09: 13 \\
\text { Sample: } 2015 \mathrm{M} 012019 \mathrm{M} 12 \\
\text { Included observations: } 60\end{array}$} \\
\hline Variable & Coefficient & Std. Error & t-Statistic & Prob. \\
\hline $\begin{array}{l}\mathrm{c} \\
\mathrm{X}_{1} \\
\mathrm{X} 2 \\
\mathrm{X} 3 \\
\mathrm{X}_{4}\end{array}$ & $\begin{array}{r}25709237 \\
-0.088679 \\
-0.049098 \\
3193316 \\
-76.66687\end{array}$ & $\begin{array}{c}31590548 \\
0.137994 \\
0.670893 \\
3782489 \\
2860.890\end{array}$ & $\begin{array}{r}0.813827 \\
-0.642629 \\
-0.073183 \\
0.844237 \\
-0.026798\end{array}$ & $\begin{array}{l}0.4193 \\
0.5231 \\
0.9419 \\
0.4022 \\
0.9787\end{array}$ \\
\hline $\begin{array}{l}\text { R-squared } \\
\text { Adjusted R-squared } \\
\text { S.E. of regression } \\
\text { Sum squared resid } \\
\text { Log likelihood } \\
\text { F-statistic } \\
\text { Prob(F-statistic) }\end{array}$ & $\begin{array}{r}0.035542 \\
-0.034601 \\
9134668 \\
4.59 \mathrm{E}+15 \\
-1044.181 \\
0.506706 \\
0.730953\end{array}$ & \multicolumn{2}{|c|}{$\begin{array}{l}\text { Mean dependent var } \\
\text { S.D. dependent var } \\
\text { Akaike info criterion } \\
\text { Schwarz criterion } \\
\text { Hannan-Quinn criter. } \\
\text { Durbin-Watson stat }\end{array}$} & $\begin{array}{r}12079451 \\
8980620 . \\
34.97271 \\
35.14724 \\
35.04097 \\
2.075309\end{array}$ \\
\hline
\end{tabular}

Gambar 8. Hasil Uji Glejser

Sumber: Hasil olah data Eviews 9

Berlandaskan output di atas, terlihat bahwa nilai p X1 (pembiayaan BUS devisa) sebesar 0,5231, nilai p X2 (pembiayaan syariah LPEI) sebesar 0,9419, nilai p X3 (inflasi) yaitu 0,4022 dan nilai p X4 (kurs) yaitu 0,9787 lebih besar dari signifikansi $(0,05)$. Kemudian, ditarik kesimpulan bahwa masing-masing variabel terhindar dalam masalah heteroskedastisitas.

4. Uji Autokerlasi

Berikut merupakan hasil dari pengujian DW:

\begin{tabular}{|c|c|c|c|c|}
\hline Variable & Coefficient & Std. Error & t-Statistic & Prob. \\
\hline c & $-1.34 E+08$ & 54207907 & -2.468547 & 0.0167 \\
\hline $\mathrm{x}_{1}$ & 0.328298 & 0.236791 & 1.386447 & 0.1712 \\
\hline$\times 2$ & 3.741869 & 1.151221 & 3.250349 & 0.0020 \\
\hline$x_{3}$ & -9522246 & 6490575 . & -1.467088 & 0.1480 \\
\hline $\mathrm{X} 4$ & 16353.99 & 4909.155 & 3.331325 & 0.0015 \\
\hline R-squared & 0.615447 & \multicolumn{2}{|c|}{ Mean dependent var } & $1.86 \mathrm{E}+08$ \\
\hline Adjusted R-squared & 0.587480 & \multicolumn{2}{|c|}{ S.D. dependent var } & 24404819 \\
\hline S.E. of regression & 15674664 & \multicolumn{2}{|c|}{ Akaike info criterion } & 36.05264 \\
\hline Sum squared resid & 1. $35 E+16$ & \multicolumn{2}{|c|}{ Schwarz criterion } & 36.22717 \\
\hline Log likelihood & -1076.579 & \multirow{2}{*}{\multicolumn{2}{|c|}{$\begin{array}{l}\text { Hannan-Quinn criter. } \\
\text { Durbin-Watson stat }\end{array}$}} & 36.12091 \\
\hline F-statistic & 22.00582 & & & 1.836875 \\
\hline Prob(F-statistic) & 0.000000 & & & \\
\hline
\end{tabular}

Gambar 9. Hasil Pengujian Durbin - Watson

Sumber: Hasil pengolahan data Eviews 9

Berdasar output tersebut, nilai DW sebesar 1,836875. Dengan ketentuan $d u<d<4$-dL, sehingga hasil yang didapat yakni $1,7274<1,836875<2,5557$. Untuk itu, kesimpulannya dalam model regresi yang telah dibentuk tidak ada masalah autokorelasi.

\subsubsection{Koefisien Determinasi dan Uji Hipotesis}

Setelah lolos uji asumsi klasik, dilakukanlah uji regresi linier berganda. Gambar di bawah merupakan hasil dari uji regresi tersebut: 


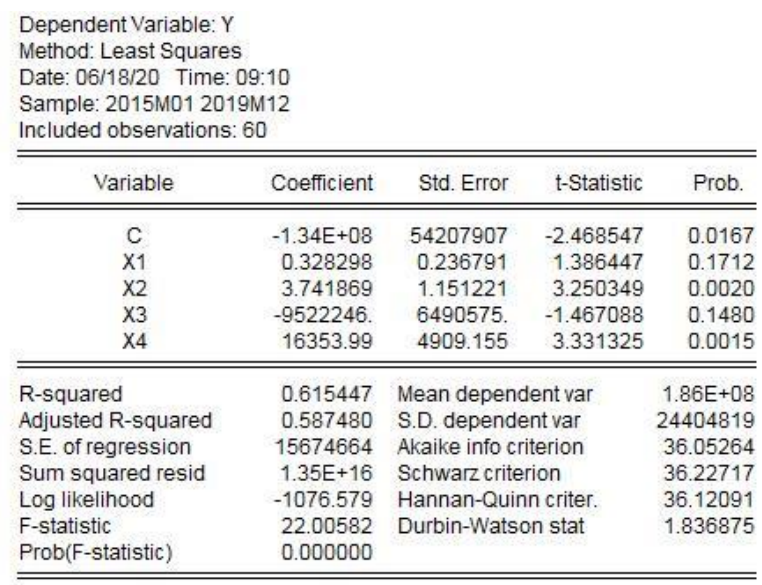

Gambar 10. Hasil Pengujian Regresi Berganda

Sumber: Hasil olah data Eviews 9

Koefisien determinasi dipakai untuk menakar kapabilitas model dalam menguraikan variasi variabel dependen. Koefisien determinasi diamati dari nilai adjusted R2 yakni 0,615447, maka 61,54\% ragam variabel dependen dapat diterangkan oleh ragam variabel-variabel independen yang digunakan. Sementara itu, 38,46\% kurangnya diterangkan oleh variabel lain diluar model.

Uji statisik F dipakai untuk mendapati apakah seluruh variabel independen mengantongi pengaruh secara bersamaan atau simultan pada variabel dependen dalam model. Berdasarkan hasil olah data, nilai $\mathrm{p}$ F-statistik adalah $0,0000<0,05$ sehingga variabel independen secara bersamaan berdampak signifikan pada variabel dependen.

Pengujian statistik $\mathrm{t}$ dipakai untuk mendapati seberapa besar dampak satu variabel independen pada variabel dependen melalui asumsi konstannya variabel lain. Berdasarkan hasil olah data, uraian uji statistik t ialah:

a. Pengaruh pembiayaan BUS devisa terhadap nilai ekspor Indonesia dilihat dari:

- Nilai coefficient X1 adalah positif

- $\quad t$ hitung $(1,386447)<\mathrm{t}$ tabel $(1,67303)$

- Prob t - statistik X1 =0,1712>0,05

Sehingga pembiayaan yang disalurkan BUS devisa secara parsial tak berpengaruh signifikan pada nilai ekspor Indonesia.

b. Pengaruh pembiayaan syariah LPEI terhadap nilai ekspor Indonesia dilihat dari:

- Nilai coefficient X2 adalah positif

- $\quad$ hitung $(3,250349)>\mathrm{t}$ tabel $(1,67303)$

- Prob t - statistik X2 sebesar 0,0020<0,05

Sehingga pembiayaan syariah LPEI secara parsial berpengaruh positif signifikan pada nilai ekspor Indonesia.

c. Pengaruh inflasi terhadap nilai ekspor Indonesia dilihat dari:

- Nilai coefficient X3 adalah negatif

- $\quad t$ hitung $(-1,467088)<\mathrm{t}$ tabel $(1,67303)$

- Prob t - statistik X3 sebesar 0,1480 >0,05

Sehingga inflasi secara parsial tak berpengaruh signifikan pada nilai ekspor Indonesia.

d. Pengaruh kurs terhadap nilai ekspor Indonesia dilihat dari:

- Nilai coefficient X4 adalah positif

- $\quad t$ hitung $(3,331325)>\mathrm{t}$ tabel $(1,67303)$

- Prob t - statistik X4 sebesar 0,0015<0,05

Sehingga kurs secara parsial berpengaruh positif signifikan pada nilai ekspor Indonesia. 


\subsection{Pembahasan}

\subsubsection{Pengaruh Pembiayaan BUS Devisa Terhadap Ekspor Indonesia}

Hasil olah data memperlihatkan bahwa pembiayaan BUS devisa secara parsial tidak berpengaruh signifikan dengan arah pengaruh positif terhadap nilai ekspor Indonesia. Tidak berpengaruh signifikannya pengaruh tersebut diduga disebabkan oleh pembiayaan yang diberikan oleh perbankan syariah masih banyak yang bersifat konsumtif dengan akad jual beli seperti murabahah daripada penggunaan akad kerja sama seperti musyarakah dan mudharabah untuk sektor riil, seperti terlihat pada tabel 3. Pembiayaan murabahah pada tahun 2015 sampai 2019 tercatat lebih tinggi daripada pembiayaan mudharabah dan musyarakah. Meskipun pembiayaan musyarakah tercatat lebih tinggi dari pembiayaan mudharabah, tetapi pembiayaan murabahah tercatat jauh lebih tinggi.

Hal lain yang dapat menjadi penyebab pembiayaan BUS devisa tidak signifikan terhadap ekspor Indonesia karena kredit perbankan konvensional lebih mendominasi daripada permbiayaan perbankan syariah. Kredit bank konvensional lebih besar efeknya dibandingkan pembiayaan bank syariah kepada pertumbuhan ekonomi (Setiawan, 2020). Maka dari itu, pembiayaan yang disalurkan perbankan syariah belum berpengaruh terhadap ekspor sebagai salah satu barometer pertumbuhan ekonomi.

Tabel 3. Data Pembiayaan berdasarkan akad BUS tahun 2015-2019

\begin{tabular}{|l|r|r|r|r|r|}
\hline Jenis Akad & $\mathbf{2 0 1 5}$ & $\mathbf{2 0 1 6}$ & $\mathbf{2 0 1 7}$ & $\mathbf{2 0 1 8}$ & $\mathbf{2 0 1 9}$ \\
\hline Mudharabah & 8,431 & 8,012 & 7,050 & 5,889 & 5,814 \\
\hline Musyarakah & 47,455 & 54,139 & 60,486 & 68,652 & 84,609 \\
\hline Murabahah & 93,647 & 110,101 & 114,534 & 118,181 & 122,758 \\
\hline
\end{tabular}

Sumber: OJK, data diolah

\subsubsection{Pengaruh Pembiayaan Syariah LPEI Terhadap Ekspor Indonesia}

Hasil dari pengujian data menunjukkan bahwa pembiayaan syariah LPEI secara parsial berpengaruh positif signifikan pada nilai ekspor Indonesia. Hasil tersebut sudah selaras dengan rumusan hipotesis, dimana pembiayaan syariah yang disalurkan oleh LPEI dapat menyokong ekspor Indonesia. Dapat dikatakan bahwa Lembaga Jasa Keuangan Khusus Syariah termasuk LPEI, pangsa pasarnya lebih besar daripada Asuransi serta Lembaga Pembiayaan Syariah karena masyarakat cenderung mempercayakan dananya di LJKK (Setyowati, Sartika, \& Setiawan, 2019).

\subsubsection{Pengaruh Inflasi Terhadap Ekspor Indonesia}

Hasil pengujian yang dilaksanakan menunjukkan inflasi secara parsial tidak berpengaruh signifikan dengan arah pengaruh negatif terhadap nilai ekspor Indonesia. Hasil tersebut dapat disebabkan oleh keadaan inflasi di Indonesia pada tahun 2015 - 2019 masih ada dibawah 10\%. Inflasi dengan laju pertumbuhan secara perlahan dengan posisi dibawah 10\% dikategorikan sebagai inflasi ringan yang tidak terlampau mengakibatkan distorsi terhadap harga relatif (Nanga, 2005). Hal tersebut mengakibatkan inflasi tak mempengaruhi ekspor Indonesia pada tahun 2015 - 2019.

\subsubsection{Pengaruh Kurs Terhadap Ekspor Indonesia}

Hasil pengujian yang dilakukan menunjukkan kurs secara parsial berpengaruh positif signifikan pada nilai ekspor Indonesia. Melemahnya rupiah justru sering menjadi tekanan terhadap sisi ekspor (Marbun, 2017). Tekanan tersebut membuat depresiasi kurs menurunkan ekspor Indonesia. Pengaruh positif tersebut dapat disebabkan oleh mahalnya biaya pembelian bahan dan komponen yang harus diimpor (Darwanto, 2014). Selain itu, diungkapkan pula bahwa depresiasi kurs di Indonesia belum menunjukkan kekuatan instrumen dalam meningkatkan daya saing ekspor (Darwanto, 2014). Ketika kurs rupiah terdepresiasi, dimana rupiah melemah terhadap dollar 
Amerika Serikat dapat membuat ekspor Indonesia turun. Sebaliknya, saat kurs rupiah terapresiasi, dimana rupiah menguat terhadap dollar Amerika Serikat dapat meningkatkan ekspor Indonesia.

\subsubsection{Pengaruh Pembiayaan BUS Devisa, Pembiayaan Syariah LPEI, Inflasi dan Kurs Terhadap Ekspor Indonesia}

Berdasarkan pada hasil olah data, nilai p F-statistik adalah 0,0000, di mana hasil tersebut lebih kecil dari 0,05, kemudian pembiayaan yang disalurkan baik dari BUS devisa maupun LPEI, inflasi serta kurs secara bersamaan berpengaruh signifikan terhadap ekspor Indonesia.

\section{Penutup}

\subsection{Kesimpulan}

Pembiayaan yang disalurkan BUS devisa masih banyak yang bersifat konsumtif dengan akad jual beli seperti murabahah daripada penggunaan akad kerja sama seperti musyarakah dan mudharabah untuk sektor riil. Sementara, pembiayaan syariah yang disalurkan oleh LPEI sudah mempengaruhi peningkatan ekspor Indonesia. Inflasi tidak berpengaruh terhadap ekspor Indoensia karena pada tahun 2015-2019 masih dalam keadaan inflasi kategori ringan. Sedangkan, melemahnya rupiah sering menjadi tekanan terhadap sisi ekspor karena mahalnya biaya pembelian bahan dan komponen yang harus diimpor. Sehingga, depresiasi kurs yang seharusnya dapat menaikkan ekspor justru menurunkan ekspor Indonesia.

\subsection{Saran}

Bagi perbankan syariah disarankan untuk meningkatkan penyaluran pembiayaan syariah untuk sektor riil dengan akad kerja sama seperti musyarakah dan mudharabah dibandingkan penyaluran yang bersifat konsumtif serta memperbanyak penyaluran pembiayaan syariah kepada UMKM yang berorientasi ekspor (UKME) guna meningkatkan nilai ekspor Indonesia.

Bagi divisi syariah LPEI disarankan untuk mengembangkan dan mengoptimalkan pelayanan pembiayaan syariah. LPEI disarankan juga untuk tetap memperhatikan aspek kepatuhan terhadap prinsip syariah dalam kegiatan operasional sebagai unit usaha syariah

Untuk peneliti selanjutnya disarankan untuk memperluas ruang lingkup kepada aspek pengaruh pembiayaan terhadap ekspor perkomoditi serta menambahkan variabel penelitian, seperti pembiayaan berdasarkan akad, penanaman modal dalam negeri beserta penanaman modal asing.

\section{Daftar Pustaka}

Anshari, M. F., Khilla, A. E., \& Permata, I. R. (2017). Analisis Pengaruh Inflasi dan Kurs terhadap Ekspor di Negara Asean 5 Periode tahun 2012-2016. Jurnal Info Artha, Vol. 1, No. 2, 121-128.

Apriyanthi, R., Purbayati, R., \& Setiawan. (2020). Faktor-Faktor yang Mempengaruhi Pembiayaan Sektor Konstruksi Pada Perbankan Syariah di Indonesia. Jurnal Ekonomi dan Perbankan Vol 5, No 1, 25-35.

Azaria, V., \& Irawan, A. (2019). Pengaruh Inflasi, Nilai Tukar Rupiah, dan Harga Terhadap Volume Ekspor Indonesia Komoditas Kelautan dan Perikanan Menurut Provinsi. Journal of Applied Managerial Accounting Vol.3 No.1.

Badan Pusat Statistik. (2020). Nilai Ekspor. Diakses dari Badan Pusat Statistik: https://www.bps.go.id/indicator/8/196/6/nilai-ekspor.html

Ball, D. A. (2005). Bisnis Internasional: Tantangan Persaingan Global. Dialibbahasakan oleh Syabrizal Noor. Jakarta: Salemba Empat.

Bank Indonesia. (2019). Database Profil UMKM Produk Ekspor. Jakarta: Bank Indonesia. 
Bank Indonesia. (2020). Moneter: Data Inflasi. Diakses dari Bank Indonesia: https://www.bi.go.id/id/moneter/inflasi/data/Default.aspx

Darwanto. (2014). Adakah Fenomena Marshall-Lerner Condition dan J-Curve di Indonesia. Jurnal Bisnis dan Ekonomi (JBE), 18-29.

Farhadi, A., Ghaffari, F., \& Taghavi, M. (2010). Factors Affecting the Non-Oil Exports In Iranian Economy. Iranian Economic Review, Vol.15, No.27, 133-154.

Ginting, A. M. (2013). Pengaruh Nilai Tukar Terhadap Ekspor Indonesia. Buletin Ilmiah Litbang Perdagangan, VOL.7 NO.1.

Gururaj, B., Satishkumar, M., \& Kumar, M. K. (2016). Analysis of factors affecting the performance of exports in India. International Journal of Agriculture, Environment and Biotechnology, 613-616.

Kasmir. (2002). Dasar-Dasar Perbankan. Jakarta: Raja Grafindo Persada.

Mahrus, M. L., \& Yulianto, I. (2017). Analisis atas Pembiayaan Ekspor Nasional Syariah pada Lembaga Pembiayaan Ekspor Indonesia. Substansi Vol. 1 No. 2.

Mankiw, N. G. (2003). Macroeconomic 5th edition. U.S: Worth Publishers Inc.

Mankiw, N. G. (2006). Principles of Economics. Edisi Ketiga. Jakarta: Salemba Empat.

Marbun, S. (2017). Analisis Faktor-faktor yang Mempengaruhi Ekspor Nonmigas Indonesia Tahun 1970-2004. Jurnal Ekonomi Vol 6. No. 1, 31-42.

McEarhern, \& Wiliam, A. (2000). Ekonomi Makro. Jakarta: Salemba Empat.

Nanga, M. (2005). Makro Ekonomi: Teori, Masalah dan Kebijakan. Edisi ke 2. Jakarta: PT. Raja Grafindo Persada.

OJK. (2018, Desember 12). Publik: Direktori Perbankan Indonesia 2018. Diakses dari Otoritas Jasa Keuangan: https://ojk.go.id/id/kanal/perbankan/data-dan-statistik/Direktori-PerbankanIndonesia-Baru/Pages/Direktori-Perbankan-Indonesia-2018.aspx

OJK. (2020). Statistik IKNB Syariah. Diakses dari OJK: https://www.ojk.go.id/id/kanal/syariah/data-dan-statistik/iknb-syariah/Default.aspx

Pemerintah Indonesia. (2009). UU No. 2 Tabun 2009 tentang Lembaga Pembiayaan Ekspor Indonesia. Lembar RI Tahun 2009 No.2. Jakarta: Sekretariat Negara.

Rahman, M. M. (2010). The Factors Affecting Bangladesh's Exports: Evidence From The Gravity Model Analysis. The Journal of Developing Areas, Volume 44, Number 1, 229-244.

Rusmita, S. A., \& Cahyono, E. F. (2016). Pengaruh Variabel Ekonomi Makro, Pembiayaan dari Bank Umum Syariah dan IKNB Syariah Terhadap Ekspor Indonesia. Nisbah Vol. 2 No. 2.

Samuelson, P. A., \& Nordhaus, W. D. (1994). Makroekonomi. Edisi keempat belas. Jakarta: Penerbit Erlangga.

Setianto, W. (2014). Analisis Faktor-Faktor yang Mempengaruhi Ekspor Tekstil Indonesia Periode 2007-2011. Economics Development Analysis Journal 3 (1), 124-134.

Setiawan, I. (2020). Analisis Peran Perbankan Terhadap Pertumbuhan Ekonomi di Indonesia: Bank Syariah Versus Bank Konvensional. Jurnal Akuntansi, Ekonomi dan Manajemen Bisnis Vol.8 No.1, 52-60.

Setyowati, D. H., Sartika, A., \& Setiawan. (2019). Faktor-Faktor yang Mempengaruhi Pangsa Pasar Industri Keuangan Syariah Non-Bank . Jurnal Iqtisaduna Vol. 5 No. 2, 169-186.

Shemi, H. (2019, September 18). Business Economy: 3 Dampak Perang Dagang Amerika Vs China terbadap Indonesia. Diakses dari idntimes: https://www.idntimes.com/business/economy/helmi/3-dampak-perang-dagang-amerika- 
vs-china-terhadap-indonesia/full

Sugiyono. (2011). Metode Penelitian Kuantitatif Kualitatif dan R\&DD. Bandung: Alfabeta.

Tripuspitorini, F. A., \& Setiawan, S. Pengaruh Faktor Makroekonomi Terhadap Pertumbuhan Dana Pihak Ketiga Pada Bank Umum Syariah di Indonesia. Jumal Riset Akuntansi dan Keuangan, 8(1), 121-132.

Wardhana, A. (2011). Analisis Faktor-Faktor yang Mempengaruhi Ekspor NonMigas Indonesia ke Singapura Tahun 1990-2010. Jurnal Manajemen dan Akuntansi. Vol.12. No.2, 99-102.

Worldbank. (2020, September 6). The World Bank. Diakses dari Data: https://data.worldbank.org/indicator/TX.VAL.MRCH.XD.WD?end=2018\&locations $=\mathrm{M}$ Y-BN-ID\&name_desc $=$ false $\&$ start $=2014 \& v i e w=$ chart

Yanti, N. W., \& Sudriman, I. W. (2017). Pengaruh Kurs Dollar Amerika Serikat, Inflasi, dan Harga Ekspor Terhadap Nilai Ekspor Pakaian Jadi Indonesia. E-Jurnal Ekonomi Pembangunan Universitas Udayana VOL. 6, No. 3.

Yee, L. S., \& dkk. (2016). Determinants of Export: Empirical Study in Malaysia. Journal of International Business and Economics Vol. 4, No. 1, 61-75. 